\title{
The Capital Structure of Russian Companies: Testing Trade- off Theory versus Pecking Order Theory
}

\author{
Irina V. Ivashkovskaya ${ }^{5}$, Maria S. Solntseva ${ }^{6}$
}

The capital structure researches, carried out on the emerging markets, are mainly devoted to the analysis of the companies' choice determinants of the debt to equity ratio. The fact that these problems stir a lot of interest to day may be explained by a number of reasons and, first of all, by lasting substantial capital market institutions' differences, the level and factors of investment risks that differ from those of the countries with developed market economy. The question of evaluating the degrees of influence similar determinants have on the long-term financial development of companies operating in different structures of the capital market is being posed. The dynamics and driving forces of possible changes in the emerging company capital structures on such markets are still to be investigated. Finally, there is a separate substantive issue of assessing the role of capital structure and its potential contribution in maximizing company value on the emerging markets.

This article is thus aimed at constructing a model that could describe the capital structure choice of the Russian major public companies. The two basic capital structure theories are being tested: the Pecking Order Theory and the Trade-off Theory. The article is presented in the following way: in the first part we give an overview of the research papers on the problem of capital structure in the emerging markets, the second part focuses on the methods used for testing the above mentioned theories and analyses of our sample of the Russian data and methodology, and, finally, in the third part we introduce and interpret the results of the empirical analysis.

\section{The Capital Structure Research Based on the Emerging Markets Data}

The research in the area of capital structure in the emerging markets has only recently appeared. It is mostly focused on the determinants of debt to equity choice. The capital structure choice has always been one of the crucial elements of the whole financial architecture of the firm [Myers, 1999] which includes debt - equity, firm's ownership structure and instruments of internal corporate governance and control and, thus, becomes the key factor of the firm's value. It has been also demonstrated that the capital structure is vital for the appropriate development of the relationships between company's stakeholders [Titman et al., 1997].

There are heaps of papers devoted to the capital structure on the developed markets whereas emerging markets still lack thorough investigation. The researches of the latter are mostly represented by a limited number of European and Asian countries, such as Hungary [Nivorozhkin, 2002]; India [Bhaduri, 2002]; the Czech Republic, Turkey, Taiwan, Thailand, [Harvey et al., 2004]; Thailand [Wiwattanakantang, 1999]. The case is even more dramatic when speaking about Russian companies. Most of the literature on capital structure in Russian firms ends up with a statistics devoid of any analysis of the modern corporate finance methodology.

One could put forward an argument that this situation should not be a case of worry when speaking about Russian companies because we could simply keep in mind the results of the studies already conducted on the developed capital markets data.

\footnotetext{
${ }^{5}$ Professor, Head of Department of Corporate Finance, Faculty of Economics State University-Higher School of Economics, Moscow; Director, Corporate Finance Center

${ }^{6}$ Corporate Finance Center, Faculty of Economics State University-Higher School of Economics, Moscow Выпуск \#2, 2007

(c) Электронный журнал Корпоративные Финансы, 2007
} 
Indeed, a number of papers (for example [Mitton, 2006]) have already shown the constancy of the convergence tendency of the developed and emerging markets. The latter are gradually reaching the formers' debt levels. This fact supports the idea of using the results of the developed markets researches when dealing with any capital structure problems on the emerging markets. This way may be certainly preferable since the quality of the financial data of these countries' companies is much higher than that of the others. However, the matter is not as obvious as that. It is necessary to be absolutely sure that the companies, operating on this or that capital market, actually follow the worldwide tendencies and that they choose their capital structure following the same theories. Only given the knowledge that a concrete capital market development does not break the general global trends, you could use the results of the previous researches.

The research of Booth-Maksimovic [Booth et al., 2001], based on the sample data of 10 countries with growing capital markets, along with the traditional factors of capital structure choice analyzes the influence of such macroeconomic indexes as:

- The economic growth rate

- The market capitalization of the stock market versus the GDP

- The volume of transactions on the financial market

- Financial mediation as a percentage of the GDP

As the result, the researchers found out some common features in the choice of debt to equity capital characteristic of the growing economies.

Booth et al. [Booth et al., 2001] found out that debt ratios were correlated with mostly the same factors both in the USA market and many other developed countries. The debt ratios were lower for more profitable firms with fewer tangible assets. The authors thought that the variables controlling information differences and agency costs were strong in these countries and the impact of these factors had to be considered greater than in the developed economies.

It was also revealed by the authors that institutional features matter. While the traditional determinants influence in the same way in any country, the research results presented systematic differences in the way debt ratios depend on such country factors as GDP growth rates, inflation rates, and the development of capital markets.

Most researches of this group of countries reveal the dependence of the decisions of long-term development finance on the traditional factors: profitability, tangible assets share, taxes and growth opportunities. One of the most accurately performed researches [Pandey, 2001] has shown identical influence of the factors: as the result of the model, the capital structure of the analyzed companies substantially depends on the profitability of the assets and the company size, its growth rate, risk level and the share of tangible assets. Herewith, the effect of the company investment opportunities on its capital structure is insignificant. The research has shown that the capital structure make up of the Malaysian companies corresponds to the Pecking order theory. The Hungarian companies' data research [Nivorozhkin, 2002] has shown a low level of debt and the dependence of their capital structures on the share of tangible assets, company size and the return on total assets. The dynamic model developed for India [Bhaduri, 2002] assumes that the company capital structure is influenced on by such factors as its growth rate, cash flow, size, uniqueness, and branch parameters. According to the model, the costs of restructuring are present on the Indian capital market and are different for short and long-term borrowings.

Apart from the traditional factors the researches under consideration reveal the influence of specific factors. The analysis of the Hungarian companies has shown that companies whose main shareholder is the state or those operating in the industrial sector of the economy, have a bigger share of debt [Nivorozhkin, 2002]. 
The research of the Thai companies [Wiwattanakantang, 1999] has revealed that the capital structure of the quoted companies is also heavily influenced on by company property structure. However, the impact of the factors connected with the establishment of corporate management is low.

Summarizing the results of capital structure determinants on the emerging markets it is necessary to stress that the traditional factors are mostly identical for all countries. What differs is the degree of the influence. However, for the emerging markets the factors that intensify or reduce information asymmetry are significant.

From the formal point of view most researches of capital structure determinants on the emerging markets are represented by linear regressions that differ by the set of regressors, kind of dependant variables and type of data ${ }^{7}$. The most typical model could be written as follows:

$$
L=f(N D T, \text { Tangibility, Profitability, Risk, Size, Agency), }
$$

Where the debt level is a function of a set of factors.

As a rule, the dependent variable is set as book ratio (divided by total assets) and market ratio (divided by the sum of total liabilities and capitalization) of total debt: $\mathrm{BL}=\mathrm{BVTD} / \mathrm{BVTA}, \mathrm{ML}=\mathrm{BVTD} /(\mathrm{BVT}$ liabilities $+\mathrm{MV}$ equity $)$. Other variants include breaking total debt into short term and long term parts, calculating liabilities as a percentage of total assets or computing different active debt variables ratios to capital invested.

The description of independent variables needs more attention. The tangibility factor (hypothecation value, the degree of assets materiality) is usually described by a number of proxies which aim at different purposes. Thus market-to-book is thought to be a proxy for investment opportunities by some authors. They assume that the more the growth opportunities of a company (represented by its market value) the more is the variable. On the other hand, the trade-off theory suggests that the market-to-book ratio could stand for salvage value. In other words, the higher the variable the lower are the firm's opportunities to attract debt financing. The second proxy PPE/TA (property-plantequipment/total assets) stands for the hypothecation value of the company. The higher the variable the higher are the opportunities to borrow. Other types of assets (except PPE) could be used to build this kind of variables [Bhaduri, 2002].

Profitability could be calculated as earnings before interest and tax divided by total assets. There is no common vision of this variable. Pecking order followers suppose that more profitable companies may rely on their internal funds which means that the higher the profitability the less is the debt of the company. Quite the contrary is the tradeoff theory's view. It supposes that a more profitable firm has more chances to acquire additional credit and, consequently, to increase its debt.

Business risk variable is usually calculated as standard deviation of the first differentiation of sales during 5 years divided by the medium level of total assets during the same period. It is obvious that companies with higher risk have to rely on their internal financing funds.

While adding size variable into regressions it is essential to keep in mind its ambiguous character. On the one hand, the larger the company the more chances it has to get a credit other things being equal. Agency theory argues for the same influence direction but explains it by the lower level of information asymmetry in large companies that should lead to more confidential relationship between managers and outside investors and, thus, to a higher debt ratio. However, there exists another opinion [Wiwattanakantang, 1999] demonstrating that it is more profitable for large companies

${ }^{7}$ cross-section or panel data 
with low level of information asymmetry to issue equity and reduce debt. One of the variants of calculating Size variable is to compute natural logarithm of total sales. Another way is to find the logarithm of total assets.

The tax shield variable could be represented by debt tax (DT) shield or by non debt tax shield (NDT) to express the influence of tax benefits on the capital structure decision making. The trade-off theory suggests that the increase in debt financing should be based on the debt tax shields due to the interest deduction when calculating profit before taxes. But there are also other tax shields like amortization that should lead to less debt. NDT reflects amortization benefits and is calculated as amortization payments divided by total assets.

Agency dummy variables are represented by numerous proxies such as:

- Family ownership

- Conglomerate group

- Foreign-owned

- Reputation

- Size of the board of directors

- Management owned

- Degree of ownership concentration

All these proxies could express different influences according to their interpretation.

These were the most popular variables used in the determinant analyses. Yet there could be other variables. For example, the authors of [Pandey, 2001] use lagged variables. It is especially reasonable for profitability and investment opportunities variables. One could also find proxies for company growth rate. These could be calculated as $(1+\mathrm{R})$ where $\mathrm{R}$ is found from the regression of $\lg$ Sales on time during 4 years [Pandey, 2001]. Another variant is to find investment expenses to total assets ratio [Bhaduri, 2002]. It is obvious that the higher the growth rate the more the company needs new debts. Nevertheless, the agency theory stands for the opposite influence.

Not all the papers exclude the financial sector. For example, [Nivorozhkin, 2002] simply analyzes the two sub samples using an additional dummy variable. Another variable, that sometimes measures information asymmetry level, is the age of the company. It is supposed that an older company has a higher level of information transparency [Bhaduri, 2002]. This same research uses variable dividend yield that tests signal theory according to which this variable has a negative influence. It is also possible to add factors of the company's uniqueness such as a percentage of R\&D in sales or percentage of advertisement expenses in sales [Bhaduri, 2002].

It was mentioned above that, as a rule, linear regressions are used. Nevertheless, there are other variants of analysis such as [Bhaduri, 2002] where a two-step model is introduced: a partially adjustment model to investigate the optimal capital structure establishment in conditions of positive recapitalization costs, and a factor-analytical model to explain the deviations of capital structure optimal level.

Although the capital structure determinants analysis supposes lots of independent variables, there are not many researches that pay attention to the possibility of multicollinearity. It is probably because of this factor the R-square in most of researches is quite high. Moreover, adding ownership variables could lead to endogenous problem.

\section{Methodology of the analysis}

\subsection{Capital structure of Russian companies descriptive statistics analysis}


The aim of the descriptive analysis is to introduce some basic characteristics (mean values and changes within 2002-2005) of the major Russian firms' capital structure. The dynamics is being examined separately for the whole sample and for the sub samples derived from dummy variables that stand for ownership structure (the existence of government and foreign investors as shareholders of a company). The sample analysis is conducted for public and private companies. The sample includes companies from 9 industries, so intersectional characteristics were examined as well. The descriptive analysis (as well as the following regression analysis) was obtained in Stata (version 9.0) package.

The test of the capital structure theories was conducted on the basis of the sample of the Russian companies' data for the time period from 2002 to 2005. Collecting the data combined several activities. The base was taken from Bloomberg [Bloomberg] database. Nevertheless, the base did not include appropriate information for every company, which resulted in the necessity of enlarging the sample using the information from the companies' official web-sites. Pursuing the goal of fulfilling a comparative analysis, all the added information was thoroughly checked so that it should follow the International Accounting Standards and have an independent auditor's approval ${ }^{8}$. The qualitative factors - such as the government control, public or private type of the company, existence of foreign shareholders and etc., were received from Ruslana (Bureau Van Dijk) database [Van Dijk].

The sample, thus, has the following fundamental features. It contains information about 62 large Russian companies representing 9 industries. Most of the companies are large for it is almost impossible to obtain comparable financial information for Russian companies that are of small or medium size. The financial sector was also excluded due to its specific capital structure. The panel derived is unbalanced even though part of the information was gathered from the official sites, still several figures were impossible to be found out. The reasons for such drops in financial data are the recent IPO process (and, thus, the absence of international format accounting for the earlier years) and companies' short history of (Mechel for instance started its operations only in 2003).

The quantitative data is presented in the USD millions (if another measure is not mentioned). If the data was initially published in any other currency (the Russian rubles, British pound sterling, etc.) it was transferred into the USD with the official rate of exchange taken from the Central Bank of the Russian Federation [CBR].

The crucial results of descriptive statistic analysis are the following. Book value based debt ratios exhibit identical dynamics of stable growth through 2002-2005 (14$20 \%$ on average for the long term debt ratio and $26-31 \%$ for total debt ratio). These results stay in line with the general tendencies of emerging markets. On the other hand market value based debt ratios are not as demonstrative and do not show any clear course. The subsample analysis allowed to find out that state controlled companies in general have greater credit opportunities for they are characterized by higher long- term but lower short-term debt ratios. For the firms with foreign shareholders the reallocation of short and long term debts towards the latter (with almost unchangeable total debt) prevails.

Industry analysis (Table 1) demonstrates the leadership of manufacturing (almost $44 \%$ of total debt and $63 \%$ of total liabilities) followed by consumer goods and retail trade (38\% and 55\% correspondingly). At the other extreme are telecommunication and power industry with their $9 \%$ and $11 \%$ total debt ratios.

\footnotetext{
${ }^{8}$ As the Russian accounting rules differ greatly from the international ones, only the companies with the latter accounting format were included in the sample. 
Table 1. Descriptive statistics (industry analysis, mean).

\begin{tabular}{|l|l|l|l|l|l|l|l|l|l|}
\hline \multicolumn{1}{|c|}{ Industry } & STDR & LTDR & TDR & SRDRA & LRDRA & TDRA & MSTDR & MLTDR & MTDR \\
\hline \multirow{2}{*}{$\begin{array}{l}\text { Agriculture } \\
\text { Consumer goods and }\end{array}$} & .3002803 & .0321266 & .3324069 & .3521818 & .0857714 & .4379532 & & & \\
\hline \\
retail trade
\end{tabular}

\subsection{Capital structure determinants analysis}

The analysis of the capital structure determinants included several steps. First of all, the following linear regression was tested:

$L=\alpha+\beta_{1} N D T+\beta_{2} \tan$ gibility $+\beta_{3}$ prof $+\beta_{4} \ln$ sales $+\beta_{5}$ div $+\beta_{6}$ growth $+\beta_{7}$ govern $+\beta_{8}$ public $+\beta_{9}$ foreign $+\varepsilon$

This model was checked for every dependent variable based on the book value of equity for each year and for the whole panel as well, using different versions depending on the kind of proxy. The panel analysis consisted of three models: pooled, fixed effect and random effect regressions. A series of tests (pooled versus fixed effect, BreuschPagan, Hausman) was used to choose the most appropriate model which was cleaned from insignificant factors afterwards to become the final model ${ }^{9}$.

The analysis of market value dependent variables was following the same scheme except some alterations: the public variable was dropped and the MTB variable was added:

(3)

$L=\alpha+\beta_{1} N D T+\beta_{2} \tan$ gibility $+\beta_{3}$ prof $+\beta_{4} \ln$ sales $+\beta_{5}$ div $+\beta_{6}$ growth $+\beta_{7}$ govern $+\beta_{8} M T B+\beta_{9}$ foreign $+\varepsilon$

\subsection{The Model for Testing the Pecking Order and Trade-off Theories}

\footnotetext{
${ }^{9}$ All of the tests were conducted on the $5 \%$ significance level 
The second step of the analysis was devoted directly to the Pecking Order and Trade-off Theories tests. Since this article presents the results of this very last step, we decided to pay attention to a thorough description of this part of the research.

Researches of this type are still uncommon on the emerging markets, that is why it is necessary to look at the methodology used by the developed capital markets. Unfortunately, it makes it impossible to examine the results for the emerging markets. We decided to pay attention to the papers of [Shyam-Sunder et al., 1999] и [Adedeji, 2002] for several reasons. Firstly, they present a clear methodology of research and, secondly, the latter work could be described as a logical development of the former. The basic model of [Adedeji, 2002] could be presented as:

$D_{i t}=a_{i t}+b D E F_{i t}+c N D T S_{i t-1}+d P T B V_{i t-1}+e S I Z E_{i t-1}+f S T R U C_{i t-1}+\sum_{j=1}^{n-1} g \quad I N D_{i j+j}+\sum_{k=1}^{m-1} h_{4+n+k} Y E A R_{k}+u_{i t}$

All the variables were described earlier except the Def variable, which stands for the internal financing deficit. It is calculated as a difference between the amount of cash generated internally and the total amount spent on tangible assets, tax, dividends, debt repayments and change in the working capital over a year.

Actually this is the stumbling block in all basic researches. While [ShyamSunder et al., 1999] insists on the negative value, arguing that in this case the firm tends to pay off its debt, the authors [Adedeji, 2002] consider that that is not necessarily so. In fact, it is more likely that the negative value of the internal deficit signifies the increased investment opportunities and the absence of necessity in additional external financing. Therefore, such situations should not influence the change in leverage and should be set equal to zero.

If the company sticks to the Pecking Order Theory, all the new debt should be explained by the internal company's financing deficit. Formally it can take the following expression [Shyam-Sunder et al., 1999]:

(5) $\Delta D_{i t}=a+b D E F_{i t}+e_{i t}$

The hypotheses, that the free term equals 0 if the Def variable coefficient equals 1 at the same time, should be tested. If the company sticks to the Trade-off Theory, in this case it persistently moves towards the target level of debt. Thus, the new debt should be explained by deviation from the target level of the capital structure. This model is formally expressed in the following way:

(6) $\Delta D=f\left(\right.$ Dt $\left.\arg e t_{t}-D f a c t_{t-1}\right)$

Herewith, the tested hypotheses check the calculation of the coefficient if the deviation from the target level is from 0 to 1 . A positive value of the coefficient confirms the conclusion that the company tends to achieve its target debt ratio. Whereas the coefficient $<1$ signifies positive recapitalization costs. The target level is found on the basis of the coefficients that were obtained within the capital structure determinants analysis.

We began by building up a model that checks whether the process of choosing capital structure followed the pecking order theory. In this respect we used the following model:

(7) $N L=\alpha+\beta d e f+\varepsilon$,

Where:

- NL stands for changes in the level of debt; 
- Def is described by the internal company's financing deficit, calculated as dividends paid plus investing cash flow with the deduction of operating cash flow.

When the def variable is negative it is considered as zero. We are convinced by [Adedeji, 2002] arguments.

Thus in order to find out whether the firms stick to pecking order theory the following hypotheses should be tested.

\section{Hypothesis 1:}

H0: The companies follow the pecking order theory of capital structure. Consequently, two conditions should be fulfilled simultaneously: $\alpha=0, \beta=1$. In case the $\mathrm{HO}$ is true the whole amount of new debt would be provoked by the internal companies' deficit.

H1: (otherwise) the companies do not follow the pecking order theory of capital structure.

To check the appropriateness of the trade-off theory we need an additional model. Given that the trade-off theory rests on the assumption that a firm tries to reach the target debt level, a new variable responsible for the deviation from the target level is essential for testing the theory for Russian firms. In our analysis the variable was labeled $D L$, where $L$ stands for different variants of dependent variables. Thus we used the model below:

(8) $N L=\alpha+\beta D L+\varepsilon$

The hypothesis tested could be described as follows:

Hypothesis 2:

H0: Companies build their capital structure according to the trade-off theory. In the formal language it means that $\beta>0$ and $\beta<1$. While the positive sign illustrates the company's attempts to reach the target, the unit boundary signifies the existence of recapitalization costs.

The target level of debt (variables $D L$ ) is calculated on the basis of the significant coefficients that were obtained within the determinants analysis. The determinants analysis included building linear regressions on the debt levels examined. The independent variables used are described below. structure.

H1: (otherwise) the companies do not follow the trade-off theory of capital

The next stage consisted in modeling joint regressions aimed to reveal the contribution of each theory in the capital structure choice of the Russian companies. This idea could formally be introduced in the following way:

(9) $N L=\alpha+\beta d e f+\gamma D L+\varepsilon$

Checking the coefficients' significance helps to estimate the contribution of each theory.

The concluding step depicts the relevance of the theories on the sub samples. The sample is divided according to several criteria: high or low level of debt, government control or the lack of it, existence or absence of foreign shareholders, public or closed type of the company.

As a result of the analysis we were able to make integrated conclusions of the most appropriate capital structure theory for Russian large companies.

\subsection{Variables description}

The regression analysis required a number of variables both dependent and independent, which are based on the initial sample and on the results of the descriptive 
and determinants regression models. The description of the variables is given in this section.

\subsubsection{Dependent variables}

The capital structure researches overview revealed a variety of variables responsible for the debt level measurement (for instance, authors of [Bhaduri, 2002], [Booth, 2001], [Wiwattanakantang, 1999] present different variants of leverage). For this reason it was decided to test several dependent variables in our research in order to determine the most appropriate proxy for Russian companies and have material for the comparative analysis of capital structure in other countries. Different dependent variables will also help to check the robustness of the results.

Debt level variables:

LTDR - Long-term active debt divided by the sum of total debt and book value of equity capital

MLTDR - Long-term active debt divided by the sum of total debt and market value of equity capital

MTDR - Total active debt divided by the sum of total debt and market value of equity capital

LTDRA -Long-term liabilities divided by the book value of total assets

TDRA - Total liabilities divided by the book value of total assets

Testing the pecking order and trade-off theories assumes an examination of debt level changes. Therefore new dependent variables NLTDR, NMLTDR, NMTDR, NLTDRA, NTDRA were introduced to stand for the differences in debt level variables mentioned above during the year $\mathrm{t}$ and $\mathrm{t}-1$ correspondingly.

\subsubsection{Independent variables description}

Most of the independent variables were used to find out the determinants for capital structure. These were:

NDT - Nondebt tax shield calculated as depreciation to total assets ratio.

Tax - effective tax rate calculated as income tax paid to earnings before tax. This variable is used as a proxy for tax benefits which appear with the higher debt levels.

Tangibility - tangibility is calculated as a Fixed Assets to Total Assets ratio.

Prof - profitability variable equal to earnings before interest and tax to Total Assets.

Lprof - this is a lagged variable (with a one year lag) to the previous one. The reason for introducing the variable lies in an opinion according to which a company's profitability influences the following capital structure but not the current. total sales.

Prof2 - the second proxy for profitability calculated as operating cash flow to

Lprof2 - this is a lagged variable (with a one year lag) to the Prof2 variable.

Lnsales - proxy for the size of a company calculated as a natural logarithm of a company's sales.

Lnassets - second variant of a proxy for the size of a company calculated as a natural logarithm of total assets.

Div - dividends to net income ratio is supposed to reflect signals made by companies to pay attention to their financial state.

Growth - a proxy variable for growth rate calculated as Capital expenditures to Total Assets. 
Lgrowth - this is a lagged variable (with a one year lag) to the Growth variable. The reasons for the variable are the same as for the profitability.

MTB - Market to book ratio

Govern - proxy variable for information asymmetry, dummy variable equals to 1 if a company is under the government control and 0 otherwise.

Foreign - proxy variable for information asymmetry, dummy variable equals to 1 if there are any foreign shareholders in a company and 0 otherwise. According to authors view companies, which are the subject of interest to foreign investors should be more open and thus obtain lower levels of information asymmetry. Therefore this kind of companies might model their capital structure following other rules than the others.

Public - proxy variable for information asymmetry, dummy variable equals to 1 if a company is a public one and 0 otherwise.

With a view to test the pecking order and trade-off theories a number of new variables were necessary.

Def - variable that stands for internal financing deficit. The variable is calculated as a sum of investing cash flow and dividends paid with the deduction of operating cash flow normalized by total assets.

TLev - target debt level of a company calculated on the base of determinants of capital structure analysis for the following leverage variables: LTDR, MLTDR, MTDR, LTDRA, TDRA.

$D L$ - deviation of real debt level in year t-1 from a target debt level in year t. All the abovementioned leverage proxies are used: LTDR, MLTDR, MTDR, LTDRA, TDRA.

\section{Testing the trade-off and pecking order hypotheses results}

The summarized results of the analysis are represented in Tables 2-5. The analysis could not reject either the pecking order or trade-off theory. The results are rather predictable for there could not be a theory that will perfectly describe the behavior of all companies. So the question is actually in determining the most appropriate theory that is better nowadays in explaining capital structure in Russia.

Table 2. Pecking order testing results

\begin{tabular}{|l|r|r|r|r|r|}
\hline & \multicolumn{1}{|l|}{ NLTDR } & \multicolumn{1}{l|}{ NLRDRA } & \multicolumn{1}{l|}{ NTDRA } & \multicolumn{1}{l|}{ NMLTDR } & \multicolumn{1}{l|}{ NMTDR } \\
\hline def & $.4205777^{* * *}$ & $.3246766^{* * *}$ & $.374736 * * *$ & $.4580865 * * *$ & $.6520882 * * *$ \\
\hline & & & - & & \\
Const & -.0195593 & -.0093095 & $.0213257 * *$ & -.0108269 & $-.0355343 *$ \\
\hline R-squared & 0.1021 & 0.1140 & 0.1084 & 0.1943 & 0.1857 \\
\hline Prob $>$ F & 0.0000 & 0.0000 & 0.0000 & 0.0002 & 0.0002 \\
\hline
\end{tabular}

$* * * 1 \%$ significance

** 5\% significance

* $10 \%$ significance

Table 2, revealing the results of the pecking order theory, demonstrates that internal financing deficit is a significant factor of modeling capital structure but not the only one - the parameter is in charge of $33-65 \%$ of the new debt. It should be also mentioned that the results are more evident with the leverage variables based on market value of equity. These regressions show higher coefficient of determination and internal financing deficit explains the major portion of new debt while the free term is 
insignificant (as predicted by the theory) or the significance is weak. As a result, the applied test showed impossibility to reject the pecking order theory. Meanwhile, the analysis did not approve pecking order to be the only theory to describe the choice of capital structure made by Russian companies.

Before discussing the results of trade-off testing it is necessary to pay attention to the results of the capital structure determinants analysis which are shown in Table 3. Table 3 gives influence directions of each determinant of capital structure. Based on the regression models, the coefficients differ depending on the leverage variable ${ }^{10}$.

Table 3. Summary results of determinants analysis. Cross-section and panel data

\begin{tabular}{|c|c|c|c|c|c|}
\hline \multirow[b]{2}{*}{ factor } & \multicolumn{3}{|c|}{ cross-section } & \multirow{2}{*}{$\begin{array}{c}\text { panel } \\
\text { data }\end{array}$} & \multirow[b]{2}{*}{ summary } \\
\hline & 2003 & 2004 & 2005 & & \\
\hline$N D T$ & & + & & + & + \\
\hline $\operatorname{tax}$ & & & - & - & - \\
\hline tangibility & - & + & $+/-$ & & + \\
\hline prof & + & - & - & - & - \\
\hline \multicolumn{6}{|l|}{ Lprof } \\
\hline prof2 & - & - & - & - & - \\
\hline Lprof2 & & - & & & - \\
\hline lnsales & & + & & + & + \\
\hline lnassets & & & - & & - \\
\hline div & & - & & & - \\
\hline growth & + & & + & + & + \\
\hline Lgrowth & & & + & & + \\
\hline Govern & & + & + & + & + \\
\hline Public & & - & - & - & - \\
\hline Foreign & & & + & + & + \\
\hline
\end{tabular}

Testing the trade-off theory (Table 4) did not provide any reasons to the rejection of the theory either. According to our analysis, all regressions exhibit 1\% significant coefficient responsible for the deviation from the target debt level with the value of 0,16 to 0,42 . In compliance with the trade-off theory these results show companies' attempts to reach the target capital structure as well as the existence of recapitalization costs (the coefficients do not achieve the unit level).

Table 4. Testing the trade-off theory

\begin{tabular}{|l|r|r|r|r|r|}
\hline & NLTDR & NLRDRA & NTDRA & NMLTDR & NMTDR \\
\hline & $.4153205 * *$ & $.1634709 * *$ & $.2038785 * *$ & $.2997179 * *$ & $.2843895 * *$ \\
DL & $*$ & $*$ & $*$ & $*$ & $*$ \\
\hline Const & $.0237211 * *$ & .001917 & $.0247237 * *$ & $.025043 * *$ & .0050466 \\
\hline
\end{tabular}

${ }^{10}$ The concrete models and thus coefficients for the leverage variables are not mentioned in the article being the matter of an independent research.

Выпуск \#2, 2007

(C) Электронный журнал Корпоративные Финансы, 2007 


\begin{tabular}{|l|r|r|r|r|r|} 
& & & $*$ & & \\
\hline R-squared & 0.2649 & 0.1201 & 0.1196 & 0.1473 & 0.1468 \\
\hline Prob $>F$ & 0.0000 & 0.0000 & 0.0000 & 0.0016 & 0.0012 \\
\hline
\end{tabular}

A combined theories' test is of major interest (Table 5). This step of the analysis makes it rather difficult to choose the theory that is most appropriate for Russian companies. Thus, the internal deficit has greater coefficients than the target level deviation. On the other hand, the pecking order expects the coefficient to be equal 1 when the trade-off theory supposes the coefficient to be in the interval between 0 and 1 . It should be also remembered, that the signs of the determinants' coefficients are more likely to be of those described by the pecking order (for example, the negative influence of profitability could be explained by the pecking order theory, while it could not be explained by the trade-off theory). All in all, the authors give preference to the pecking order theory.

Nevertheless, it was decided to look at the sub samples in order to find more interpretable results. When dividing the samples into those which have a high debt ratio (higher than the average level) and those with a low level of debt, the preference of the pecking order becomes evident for high debt level firms. Indeed, the significance and coefficient level of the internal deficit rises dramatically while the free term turns to be insignificant in the part of regressions. At the same time, low debt companies are more likely to be the followers of the trade-off theory for the internal financing deficit is almost insignificant in these regressions. The results match those of [Adedeji, 2002] and are definitely in conflict with the results of [Shyam-Sunder et al.,1999 ].

The dominance of the pecking order is obvious for the companies controlled by the government. For other companies one could find a slight superiority of the trade-off theory: there is an increase in deviation from the target level coefficient with a simultaneous decline of the internal financing deficit significance.

Unfortunately, no interpretable results were obtained when dividing the sample on the criterion of foreign shareholders existence. In particular, companies with foreign shareholders show the same results as the sample in whole while for other companies most of the regressions are insignificant (those that significant are more likely to be in compliance with the pecking order theory). However, the latter sub sample is not large enough to make any reasonable conclusions.

The following results were obtained for public and private companies. For the firms of the former type both theories are true with clear predominance of the pecking order. For the private Russian companies, nevertheless, only the trade-off theory could explain the capital structure choice when the pecking order is rejected for all models.

Table 5. Pecking order versus trade-off testing results

\begin{tabular}{|c|c|c|c|c|c|}
\hline & NLTDR & NLRDRA & NTDRA & NMLTDR & NMTDR \\
\hline \multicolumn{6}{|c|}{ Whole sample } \\
\hline DL & $\begin{array}{r}.3978267 * * \\
*\end{array}$ & $\begin{array}{r}.1789048 * * \\
*\end{array}$ & $\begin{array}{r}.2087244 * * \\
*\end{array}$ & $\begin{array}{r}.2285909 * * \\
*\end{array}$ & $\begin{array}{r}.2308024 * * \\
*\end{array}$ \\
\hline def & $\begin{array}{r}.3813189 * * \\
* \\
\end{array}$ & $\begin{array}{r}.3572699 * * \\
* \\
\end{array}$ & $\begin{array}{r}.3550555 * * \\
* \\
\end{array}$ & $\begin{array}{r}.3890847 * * \\
* \\
\end{array}$ & $.560355^{* * *}$ \\
\hline Const & -.0079578 & $\begin{array}{r}- \\
.0270449 * * \\
*\end{array}$ & -.0004242 & -.0016327 & $-.0299143 *$ \\
\hline R-squared & 0.3557 & 0.2581 & 0.2215 & 0.3062 & 0.2787 \\
\hline Prob $>$ F & 0.0000 & 0.0000 & 0.0000 & 0.0000 & 0.0000 \\
\hline
\end{tabular}




\begin{tabular}{|c|c|c|c|c|c|}
\hline & NLTDR & NLRDRA & NTDRA & NMLTDR & NMTDR \\
\hline \multicolumn{6}{|c|}{ High debt companies } \\
\hline DL & $\begin{array}{r}.6295865 * * \\
*\end{array}$ & $.199263 * * *$ & $\begin{array}{r}.3877972 * * \\
*\end{array}$ & $\begin{array}{r}.4869001 * * \\
*\end{array}$ & $\begin{array}{r}.3595939 * * \\
*\end{array}$ \\
\hline def & $\begin{array}{r}.4691479 * * \\
*\end{array}$ & $.46854 * * *$ & $\begin{array}{r}.4238293 * * \\
*\end{array}$ & $\begin{array}{r}.6896426^{* *} \\
*\end{array}$ & $\begin{array}{r}.8505404 * * \\
*\end{array}$ \\
\hline Const & $\begin{array}{r}.0814774 * * \\
*\end{array}$ & $\begin{array}{r}- \\
.0015068 * * \\
*\end{array}$ & $\begin{array}{r}.0742833 * * \\
*\end{array}$ & .028694 & .0242833 \\
\hline R-squared & 0.6955 & 0.3984 & 0.5557 & 0.6905 & 0.5803 \\
\hline Prob $>$ F & 0.0000 & 0.0000 & 0.0000 & 0.0000 & 0.0000 \\
\hline \multicolumn{6}{|c|}{ Low debt companies } \\
\hline DL & $\begin{array}{r}.6525316^{* *} \\
*\end{array}$ & $.1690086^{*}$ & $\begin{array}{r}.4806303 * * \\
*\end{array}$ & $.2200875^{* *}$ & $\begin{array}{r}.6168742 * * \\
*\end{array}$ \\
\hline def & -.0702049 & $.0599151 *$ & $.2399065^{-}$ & .0151865 & .0773415 \\
\hline Const & $\begin{array}{r}- \\
.0441467 * * \\
*\end{array}$ & $-.0406161 *$ & $-.0164719 *$ & $.0133766^{* *}$ & $\begin{array}{r}- \\
.0852273 * * \\
*\end{array}$ \\
\hline R-squared & 0.4465 & 0.2029 & 0.4533 & 0.2535 & 0.5287 \\
\hline Prob $>$ F & 0.0000 & 0.0001 & 0.0000 & 0.0000 & 0.0000 \\
\hline \multicolumn{6}{|c|}{ Companies under the state control } \\
\hline DL & $\begin{array}{r}.2541616^{* *} \\
* \\
\end{array}$ & .0576929 & $.0997994^{*}$ & $\begin{array}{r}.3490612 * * \\
*\end{array}$ & .1486447 \\
\hline def & $\begin{array}{r}.7212885^{* *} \\
* \\
\end{array}$ & $\begin{array}{r}.6066147 * * \\
* \\
\end{array}$ & $\begin{array}{r}.7634562 * * \\
*\end{array}$ & $\begin{array}{r}.8834301 * * \\
*\end{array}$ & $1.095503 * *$ \\
\hline Const & .0035451 & -.006315 & .0080122 & $.017586^{* * *}$ & -.0243658 \\
\hline R-squared & 0.4912 & 0.2978 & 0.4978 & 0.4670 & 0.2541 \\
\hline Prob $>$ F & 0.0000 & 0.0001 & 0.0000 & 0.0004 & 0.0221 \\
\hline \multicolumn{6}{|c|}{ Companies governed by others shareholders } \\
\hline DL & $\begin{array}{r}.4279485 * * \\
*\end{array}$ & $\begin{array}{r}.1977976^{* *} \\
*\end{array}$ & $\begin{array}{r}.2585195 * * \\
* \\
\end{array}$ & .1885737 & $\begin{array}{r}.2765502 * * \\
*\end{array}$ \\
\hline def & $\begin{array}{r}.3572467 * * \\
*\end{array}$ & $\begin{array}{r}.3420655 * * \\
*\end{array}$ & $\begin{array}{r}.3386199 * * \\
*\end{array}$ & $.325744 * *$ & $\begin{array}{r}.5246662 * * \\
* \\
\end{array}$ \\
\hline Const & $\begin{array}{r}- \\
.0184517^{* *} \\
*\end{array}$ & $\begin{array}{r}- \\
.0352548 * * \\
*\end{array}$ & $\begin{array}{r}- \\
.0129831 * * \\
*\end{array}$ & .0015451 & $.0469144^{-} *$ \\
\hline R-squared & 0.3774 & 0.2898 & 0.2618 & 0.2812 & 0.3640 \\
\hline Prob $>$ F & 0.0000 & 0.0000 & 0.0000 & 0.0036 & 0.0002 \\
\hline \multicolumn{6}{|c|}{ Companies with foreign shareholders } \\
\hline DL & $.452744 * * *$ & $.201402 * * *$ & $\begin{array}{r}.2465576^{* *} \\
*\end{array}$ & $\begin{array}{r}.2687935 * * \\
*\end{array}$ & $.277059 * * *$ \\
\hline def & $\begin{array}{r}.5269659 * * \\
* \\
\end{array}$ & $\begin{array}{r}.4819579 * * \\
*\end{array}$ & $\begin{array}{r}.5641613 * * \\
*\end{array}$ & $\begin{array}{r}.3734487 * * \\
*\end{array}$ & $\begin{array}{r}.4992335 \\
* * * \\
\end{array}$ \\
\hline Const & -.0155735 & $\begin{array}{r}- \\
.0346701 * * \\
*\end{array}$ & $\begin{array}{r}- \\
.0091674 * * \\
*\end{array}$ & .0000311 & -.0280979 \\
\hline R-squared & 0.4376 & 0.3394 & 0.3269 & 0.3471 & 0.2903 \\
\hline Prob $>$ F & 0.0000 & 0.0000 & 0.0000 & 0.0000 & 0.0001 \\
\hline
\end{tabular}




\begin{tabular}{|c|c|c|c|c|c|}
\hline & NLTDR & NLRDRA & NTDRA & NMLTDR & NMTDR \\
\hline \multicolumn{6}{|c|}{ Companies without foreign shareholders } \\
\hline $\mathbf{D L}$ & -.1492433 & -.0750623 & .2022627 & .0642511 & -.0029203 \\
\hline def & .1598349 & .0060296 & -.150312 & .3509276 & .8615853 \\
\hline Const & .0027478 & .0133803 & .047979 & -.0001497 & -.0323995 \\
\hline R-squared & 0.1323 & 0.0573 & 0.1408 & 0.1017 & 0.4606 \\
\hline Prob $>$ F & 0.1580 & 0.4644 & 0.1290 & 0.7249 & 0.1152 \\
\hline \multicolumn{6}{|c|}{ Public companies } \\
\hline DL & $\begin{array}{r}.3431725 * * \\
*\end{array}$ & $\begin{array}{r}.1814957 * * \\
* \\
\end{array}$ & $.21123 * * *$ & & \\
\hline def & $\begin{array}{r}.5112883 * * \\
* \\
\end{array}$ & $\begin{array}{r}.4691514 * * \\
* \\
\end{array}$ & $\begin{array}{r}.4743647 \\
* * * \\
\end{array}$ & & \\
\hline Const & -.0131112 & $\begin{array}{r}.0299082 * * \\
*\end{array}$ & -.0002482 & & \\
\hline R-squared & 0.3505 & 0.2988 & 0.2391 & & \\
\hline Prob $>$ F & 0.0000 & 0.0000 & 0.0000 & & \\
\hline \multicolumn{6}{|c|}{ Private companies } \\
\hline DL & $\begin{array}{r}.5869409 * * \\
*\end{array}$ & .146729 & $.2846188 * *$ & & \\
\hline def & .0988927 & .1811701 & .1603082 & & \\
\hline Const & .0226622 & -.0258976 & -.0067181 & & \\
\hline R-squared & 0.4934 & 0.1736 & 0.3156 & & \\
\hline Prob $>$ F & 0.0002 & 0.0923 & 0.0087 & & \\
\hline
\end{tabular}

On the basis of the results of the empirical tests we did not reject either the tradeoff or pecking order theory. Moreover, having dividing the sample according several criteria we revealed the superiority each of the theories has in different cases. The results meet the conditions of the common sense. In fact, there could not be a capital market where every firm acted in the same way and followed the logic of the same capital structure concept. Secondly, the domination of this or that theory deeply depends on the time period, geographic region, local economic traditions or prevalent level of debt.

\section{Bibliography}

Periodic literature:

1. Abimbola Adedeji. A cross-sectional test of Pecking Order Hypothesis Against Static Trade-off Theory on UK data. Working paper, 2002

2. Bhaduri Saumitra N.. Determinants of capital structure choice: a study of the Indian sector. Applied Financial Economics, 2002, 12, 655-665

3. Booth L., Aivazian V., Demirguc-Kunt A., Maksimovic V. Capital Structures in Developing Countries.

4. Journal of Finance. 2001. Vol. 56. No. 1. P. 87-131

5. Harvey, Campbell R., Karl V. Lins and Andrew H. Roper. The Effect Of Capital Structure When Expected Agency Costs Are Extreme. Journal of Financial Economics, 2004, v74(1,Oct), 3-30

6. Mitton Todd. Why Have Debt Ratios Increased for Firms in Emerging Markets? Brigham Young University, Working paper, 2006 
7. Myers S. Financial Architecture. European Financial Management. 1999, n.5, pp.133-141

8. Nivorozhkin E.. Capital Structures in Emerging Stock Markets: The case of Hungary.The Developing Economies, XL-2 (June 2002): 166-87

9. Opler T.C., Titman S. Designing Capital Structure to Create Shareholder Value. Journal of Applied Corporate Finance, 1997, vol.10,n.1I.

10. Pandey M.. Capital Structure and the firm characteristics: Evidence from an emerging market. Working paper, 2001

11. Shyam-Sunder L., Myers S.C.. Testing Static Trade-Off Against Pecking Order Models of Capital Structure. Journal of Financial Economics, 1999, 51, p.219244

12. Wiwattanakantang Yupana. An empirical study on the determinants of the capital structure of Thai firms. Pacific-Basin Finance Journal, 7 (1999) 371-403

Internet resources and databases:

1. Bloomberg database

2. Van Dijk (Ruslana) database

3. The Central Bank of Russian Federation site (www.cbr.ru) 